\title{
Water Quality Assessment of River Tungabhadra, India
}

\author{
Ranjith S.*, Anand V. Shivapur*†, Shiva Keshava Kumar P.**, Chandrashekarayya, G. Hiremath*** and \\ Santhosh Dhungana**** \\ *Department of Civil Engineering, VTU-PG studies, Belagavi-590018, Karnataka, India \\ **Department of Civil Engineering, PDIT Engineering College, Hosapete-583201, Karnataka, India \\ ***Department of Water and Land Management, VTU, Belagavi-590018, Karnataka, India \\ ****School of Environment, Resources and Development (SERD), Asian Institute of Technology, Pathumthani 12120, \\ Thailand \\ †Corresponding author: Anand V. Shivapur; ranjith.s009@gmail.com (Ranjith, S.)
}

Nat. Env. \& Poll. Tech.

Website: www.neptjournal.com

Received: 06-04-2020

Revised: $05-05-2020$

Accepted: 27-05-2020

Key Words:

River water quality

Tungabhadra

Water Quality Assessment

Biological analysis

\begin{abstract}
This study reports the results of an analysis performed on $40.5 \mathrm{~km}$ stretch of River Tungabhadra. The results show that there was a significant increase in all the physical and chemical variables of the river towards downstream of Harihara town, particularly in the pre-monsoon season. However, all the variables remain within the standards recommended for drinking water. Based on the Central Pollution Control Board (CPCB) guidelines, the classification of water at various segments of the research focal area is as follows: the $12.08 \mathrm{~km}$ stretch from the upstream boundary (Ingalagondi) is designated as class C, based on the Biochemical Oxygen Demand (BOD). However, from $12.08 \mathrm{~km}$ to $40.5 \mathrm{~km}$ on the stretch of downstream Harihara is designated as Class D, based on the BOD. However, in terms of dissolved oxygen (DO), the river satisfies the requirements for Class $C$ ( $>4 \mathrm{mg} / \mathrm{L}$ ) at all of the locations sampled across all periods.
\end{abstract}

\section{INTRODUCTION}

The increasing populations in both rural and urban areas and rapid industrialization has led to the production of an unmanageable amount of waste. Although the technology for waste management has also evolved considerably, it could not cater to the vast amount of waste being generated. As a result, the rate of deposit of pollutants into the environment does not correlate to the rate of their purification. These inadequacies have led to both short-term and long-term deterioration of the water sources, which are critical to human consumption. In this research, the water quality assessment will be valuable for the control of pollution and the protection of both surface and groundwater. One of the primary factors that cause an outbreak of water-borne diseases in India is the continuous deposition of untreated sewage from towns and villages into water bodies. Biodegradable substances are the core contaminants that affect the dissolved oxygen concentration, and also serves as a major indicator of polluted surface water, estimated data released by the World Health Organization (WHO) indicates that domestic waste is the cause of about $80 \%$ of water pollution in developing countries. With respect, the growth rate of the urban areas will be directly proportional to the number of people who lacks safe water and sanitation (Gleick 1993). Several types of research have been conducted to ascertain the quality of water sources. The researchers depend on the evaluation of physiochemical and biological characteristics, as well as the concentration of heavy metals on surface and groundwater (Haribhau 2012, Patil 2012, Manimaran 2012, Kumar 2012, Ranjith et al. 2019 and Ranjan 2012). The core objectives of water quality management in communities is to strike a balance between the interest of the citizens without undermining development potentials while improving and preserving the quality of water. The River Tungabhadra serves as the primary source of drinking water for the people of Davangere district in the northern parts of Karnataka state of India. It is essential to note that besides the increased deposition of domestic sewage in the region, industrial activities are also increasing as well. Given the significant impact that polluted water plays in aggravating human and aquatic health, it is essential to take urgent steps to manage the polluted segment of the river effectively. There has been no prior work that aimed at critically evaluating the water quality of the river stretch that this study focuses on. That is why this research choose the watercourse of River Tungabhadra that stretches through major towns to evaluate the seasonal variations in the quality of water. 


\section{MATERIALS AND METHODS}

\section{Study Area}

The Krishna River (the second largest river of the southern Indian peninsular) has a tributary Tungabhadra River. The recent investigation deals with up to $40.5 \mathrm{~km}$ of Tungabhadra River beginning from the Harihara Town upstream, which has a population of above 1.0 lakh. Mudenuru, Rajanahalli, Kumarapatanam, Nalawagalu, Airani and Somalapura villages are located on the stretch of the river after the town of Harihara. These villages have populations varying from 1000 to 30,000. Fig. 1 indicates the stretch of the river chosen for the study. At their location no sewage treatments plants are constructed; therefore, all the waste is disposed without any treating into the river resulting in very serious pollution issues. The MSL (sea level elevation) of the Tungabhadra river is $613 \mathrm{~m}$; having $14.52^{\circ} \mathrm{N}$ and $75.8^{\circ} \mathrm{E}$ co-ordinates. This area has a semi-arid climate, with an average to extreme summer and average winter and the erratic rainfall is low. Rain is received in this catchment area in the northeast and southwest monsoon. During May and April, dry weather with severe temperatures prevail-resulting in droughts conditions.

\section{Sampling Stations}

There were eight sampling stations selected along the stretch of the river chosen for this study. The sites were chosen based on the point source of waste discharge. The sampling stations were selected at places where the waste is well mixed to ensure that the sample taken represents the water quality of the source. The distance between the sampling stations was optimized to allow for the maximum mixing of the wastewater discharged in the river. This strategy ensures that the samples taken were true representatives of the water quality of various segments of the river.

\section{Sampling Program}

Several types of biological and physicochemical variables were chosen as benchmarks for the assessment of the River Tungabhadra water quality in the course of this study. The physical parameters are conductivity, turbidity and temperature. The chemical characteristics are Total Dissolved Solids (TDS), Chemical Oxygen Demand (COD), Dissolved Oxygen (DO), pH, alkalinity and hardness. While the biological variable: Biochemical Oxygen Demand (BOD) and Total Coliform (TC). The water samples for evaluating the physicochemical and biological parameter were taken from all of the sampling stations on the first week of each month for two consecutive years, i.e., 2017-18 and 2018-19. The "dip and grab" sampling method was used to collect the samples at a depth of $15 \mathrm{~cm}$ to avoid contamination by surface rubbles and stored at 4 degrees Celsius. At each sampling station, the samples were taken across the width of the river at $1 / 3,1 / 2$ and $2 / 3$ of the river width. The samples were analysed for the different parameters mentioned using standard methods (APHA 1998). The temperatures, $\mathrm{pH}, \mathrm{DO}$, and conductivity parameters were measured in the field at the time of sample collection with the aid of Portable Star Series Orion (USA) meter. All of the parameters measured were presented as a two-year average for both the pre-monsoon and the post-monsoon seasons.

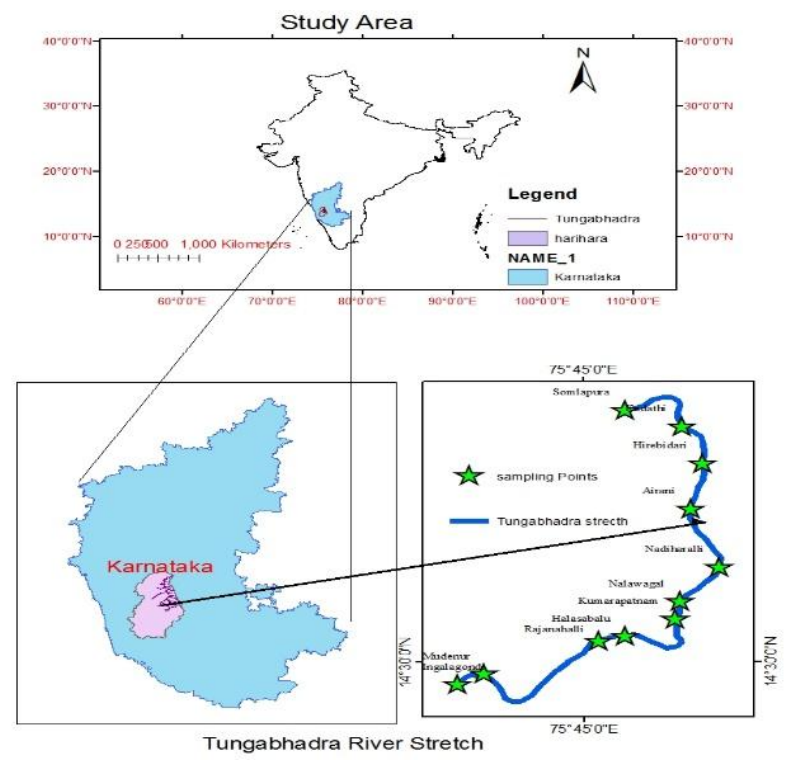

Fig. 1: The stretch of Tungabhadra river selected for the study. 
Table 1: Two-year average values during the pre-monsoon season.

\begin{tabular}{|c|c|c|c|c|c|c|c|c|c|}
\hline \multirow[t]{2}{*}{ S. No. } & \multirow[t]{2}{*}{ Parameters } & \multicolumn{8}{|c|}{ Sampling station (pre-monsoon) } \\
\hline & & SS1 & SS2 & SS3 & SS4 & SS5 & SS6 & SS7 & SS8 \\
\hline 1 & Water Temperature & 30.05 & 28.75 & 28.85 & 31.65 & 29.75 & 29.8 & 28.15 & 29.85 \\
\hline 2 & Turbidity & 5.62 & 16.34 & 14.45 & 17.67 & 14.67 & 12.75 & 11.1 & 8.3 \\
\hline 3 & conductivity & 241.6 & 301.72 & 364.62 & 408.61 & 396.1 & 365.4 & 384.7 & 450 \\
\hline 4 & $\mathrm{pH}$ & 7.24 & 7.61 & 7.85 & 8.2 & 8.16 & 7.95 & 8.1 & 7.7 \\
\hline 5 & TA & 84.84 & 141.35 & 151.6 & 168.71 & 162.28 & 153.1 & 154.7 & 151.31 \\
\hline 6 & $\mathrm{CaCO} 3$ & 86.15 & 109.65 & 121.16 & 155.36 & 154.1 & 158.6 & 160.13 & 159.8 \\
\hline 7 & TDS & 134.96 & 176.75 & 188.1 & 228.9 & 231.65 & 253.1 & 260.05 & 271.7 \\
\hline 8 & Total Coli & 1050 & 4500 & 4950 & 4700 & 4050 & 4650 & 3800 & 2100 \\
\hline 9 & Faecal coli & 450 & 1250 & 1650 & 1750 & 1255 & 1400 & 890 & 550 \\
\hline 10 & DO & 7.65 & 8.1 & 7.93 & 4.65 & 5.9 & 6.85 & 7.4 & 8.1 \\
\hline 11 & BOD & 2.9 & 5.5 & 6.5 & 10.95 & 9.1 & 7.1 & 5.04 & 4.1 \\
\hline 12 & COD & 26.73 & 40.7 & 46.1 & 59.1 & 79.6 & 66.3 & 58.33 & 61.6 \\
\hline
\end{tabular}

Table 2: Two-year average values during post-monsoon season.

\begin{tabular}{|c|c|c|c|c|c|c|c|c|c|}
\hline \multirow[t]{2}{*}{ SL.NO } & \multirow[t]{2}{*}{ Parameters } & \multicolumn{8}{|c|}{ Sampling station (post-monsoon) } \\
\hline & & SS1 & SS2 & SS3 & SS4 & SS5 & SS6 & SS7 & SS8 \\
\hline 1 & Water Temperature & 26.85 & 27.65 & 27.85 & 29.75 & 28.4 & 28.3 & 28.2 & 28.1 \\
\hline 2 & Turbidity & 4.68 & 9.63 & 9.46 & 12.64 & 10.7 & 9.86 & 10.1 & 8.75 \\
\hline 3 & conductivity & 221.6 & 270.7 & 308.16 & 371.46 & 281.8 & 327.16 & 316.1 & 410.73 \\
\hline 4 & $\mathrm{pH}$ & 7.32 & 7.78 & 7.48 & 8.41 & 8.18 & 7.61 & 7.76 & 7.34 \\
\hline 5 & $\mathrm{TA}$ & 78.74 & 127.16 & 140.05 & 138.71 & 143.16 & 138.6 & 129.7 & 148.7 \\
\hline 6 & $\mathrm{CaCO} 3$ & 71.6 & 88.7 & 93.4 & 110.67 & 102.7 & 115.21 & 118.7 & 121.6 \\
\hline 7 & TDS & 120.3 & 133.56 & 163.4 & 196.7 & 197.2 & 201.1 & 213.4 & 234.6 \\
\hline 8 & Total coli & 1100 & 4750 & 4850 & 4900 & 4600 & 3250 & 2800 & 2200 \\
\hline 9 & Faecal coli & 500 & 1450 & 1800 & 1800 & 1250 & 810 & 700 & 620 \\
\hline 10 & DO & 8.1 & 8.8 & 7.9 & 5.3 & 6.1 & 7.3 & 7.8 & 8.4 \\
\hline 11 & BOD & 2.65 & 4.85 & 5.4 & 9.5 & 8.1 & 6.4 & 4.5 & 3.25 \\
\hline 12 & COD & 20.6 & 38.6 & 41.6 & 50.1 & 59.85 & 48.6 & 46.7 & 41.25 \\
\hline
\end{tabular}

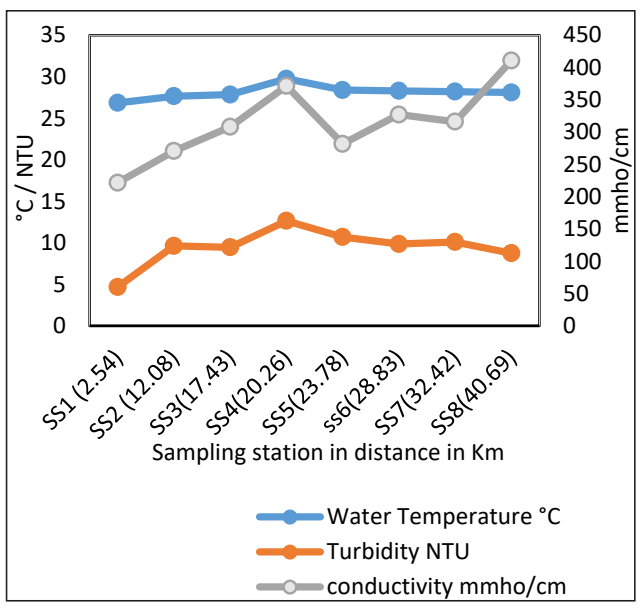

Fig. 2: Variation of temperature, conductivity and turbidity during pre-monsoon season.

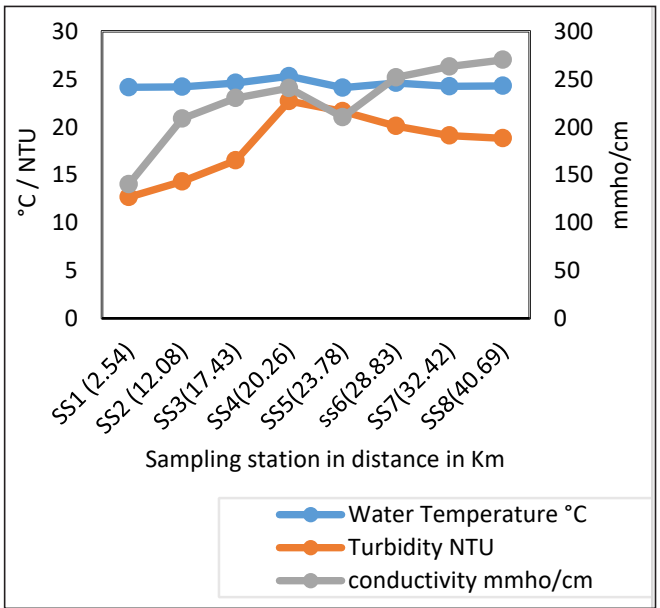

Fig. 3: Variation of temperature, conductivity and turbidity during post-monsoon season. 


\section{RESULTS AND DISCUSSION}

Tables 1 and 2 attached shows the average values of the various quality parameters at all the eight-sampling station for the post-monsoon and pre-monsoon seasons, respectively. The Figs. 2 and 3 give the graphical representation of the variation of the parameters at all the eight sampling stations during the post-monsoon and pre-monsoon seasons respectively.

Temperature: The temperature help to know the type of biological species present in the aquatic environment and also their level of activity. The variation in the temperature at the different seasons demonstrates the change in the climate of the study environment. At the pre-monsoon season, the temperature of the water varies between 28.15 to 31.65 degrees Celsius for all the eight sampling stations whereas the temperature ranges between 26.85 and 29.75 degree Celsius during the post-monsoon season.

Conductivity: The ability of the water body to carry electric current can be expressed in a numerical value called Conductivity. During the summer season, the conductivity measured at the upstream of Harihara town (SS1) as $241.6 \mu \mathrm{mhos} / \mathrm{cm}$. and it is found that the conductivity varies from 301.72 to $450.8 \mu \mathrm{mhos} / \mathrm{cm}$ in eight sampling station. However, during the winter season, the values at station-one (SS1) is observed to be $221.6 \mu \mathrm{mhos} / \mathrm{cm}$, and in rest of the station, it varies between 270.7 and $410.73 \mu \mathrm{mhos} / \mathrm{cm}$.

There was an abrupt rise in conductivity value from stations 1-2 and the gradual increase from stations 2-8. The changes in the values may be caused due to the discharge of domestic waste into the river from Harihara taluk and neighbouring villages located on the banks of the Tungabhadra river. The study carried out on River Ganga shows that the electrical conductivity increased to an extreme level during the pre-monsoon and reduces during the rainy season (Rao et al. 1990). The research carried out on the Polar River shows similar results (Khare et al. 1986). The peak value for conductivity is noted in the monsoon season at River Ganga which is located at Gazipur (Shukla et al. 1992).

Turbidity: It is expected that the domestic wastewater that finds its way into the river will add a significant amount of both organic and inorganic matter that can increase the turbidity of the river water. The turbidity values are obtained at sampling station 1 during the pre-monsoon and post-monsoon seasons are 5.62 and 4.68, respectively. However, from station $2-8$, the turbidity value varies from 8.3 to 17.7 and 8.75 to $12.64 \mathrm{NTU}$, respectively, indicating that there is a sudden increase in its value, which can be attributed to the domestic wastewater discharge at the downstream of Harihara. As the rainwater carries suspended particles and industries discharge effluents (Unni 1992, 1985), the values of turbidity increases.

pH: It should be noted that a tiny change in $\mathrm{pH}$ value also affects the quality of the water significantly. The $\mathrm{pH}$ influences other vital factors such as precipitation, trace metal complexation, biological uptake, and their respective reverse pathways. Previous studies have observed alkaline $\mathrm{pH}$ values of various riverine systems (Pal et al. 1986). At station 1, the $\mathrm{pH}$ value during the pre-monsoon and post-monsoon season was 7.24 and 7.32, respectively. For the other stations 2-8, the $\mathrm{pH}$ value varied between 7.6 and 8.2 and 7.3 and 8.4 during the pre-monsoon and post-monsoon season, respectively (Figs. 4 \& 5). Results proved that the water samples at all of the stations were slightly alkaline. However, the $\mathrm{pH}$ value increased sharply from station 1-2, and from stations 2-8, it continued to increase gradually. Pollution due to the domestic wastewater and industrial waste from Harihara Polyfiber and Grasim industries near Kumarapatanam town and other villages located along the river banks might be responsible for the increase in $\mathrm{pH}$ from stations 2 to 5 .

Alkalinity: The alkalinity of water is a measure of the capacity of the water to neutralize acids. It is essential to have a slight alkaline environment for many species to thrive. However, when the alkaline content is too high, the taste of a water sample becomes bitter. It is understanding that to reduce the alkaline content of water is the reaction between the alkaline water and cations in the aquatic environment is needed. The precipitations that result from above can cause pipes to clog and foul other water system accessories.

The average values of alkalinity $\left(\mathrm{CaCO}_{3}\right)$ measurements at Station 1 for the pre-monsoon and post-monsoon seasons were measured as 84.84 and $72.74 \mathrm{mg} / \mathrm{L}$, respectively. However, from station 2-8, the values of $\mathrm{CaCO}_{3}$ vary from 141.35 to 168.71 and 127.16 to $148.7 \mathrm{mg} / \mathrm{L}$ for the pre-monsoon and post-monsoon season, respectively.

The results show that the alkalinity levels were high during the pre-monsoon season increasing from station 1 through 8 significantly. The increase was gradual till station 5 , then the change became insignificant. The urea-laden wastewater from Harihara and the village on the river banks could be responsible for the increase in alkalinity on the downstream of Harihara.

Earlier researchers reported that the riverine system which receives a considerably high amount of sewage has its alkalinity levels above $50 \mathrm{mg} / \mathrm{L}$ (Raina et al. 1984). In the present study, the alkalinity levels at all the stations exceed 60 $\mathrm{mg} / \mathrm{L}$ across all seasons. The authors found that the alkaline content of the sampled water is within the acceptable levels of concentration (up to $200 \mathrm{mg} / \mathrm{L}$ ), as per IS: 10500, 1992.

Total hardness: The hardness of water is referred to as 
the concentration of various forms of metallic cations in a solution. The levels of hardness that are parallel to the alkalinity are referred to as "carbonate hardness." The excess hardness is termed as "non-carbonate hardness." In practical terms, the levels of hardness of water can be represented as the sum of the calcium and magnesium ions found in the solution. The average hardness levels measured at station 1 during the pre-monsoon and post-monsoon seasons are 86.15 and $71.6 \mathrm{mg} / \mathrm{L}$ as $\mathrm{CaCO}_{3}$ respectively. However, from stations 2-8, the values arrived at during the pre-monsoon and post-monsoon seasons varied between 109 to 160 , and 88 to $121 \mathrm{mg} / \mathrm{L}$ respectively. A close inspection of the results indicates a sharp increase in the values measured from station $1-2$, After that, the values increased gradually from stations 2-5. The discharge of domestic waste from Harihara and other settlements by the riverbanks is the likely cause of the increase in the water hardness. Moreover, it was found that the concentration of the hardness increases towards the summer. This change can be as a result of a decrease in the water level as well as a reduction in the velocity of the water currents. The levels of hardness of water still follow the same trend with the change in season. The analysis of the sample tested indicate, the water can be classified as moderately hard (50 to $150 \mathrm{mg} / \mathrm{L}$ as $\mathrm{CaCO}_{3}$ ) during the post-monsoon season. On the other hand, during the pre-monsoon season, the water is moderately hard from station 1-4 only. The other stations contain hard water during the pre-monsoon season. It is essential to note that the water hardness across all seasons are within the acceptable limit for drinking water designated at $300 \mathrm{mg} / \mathrm{L}$ (IS: 10500,1992 )

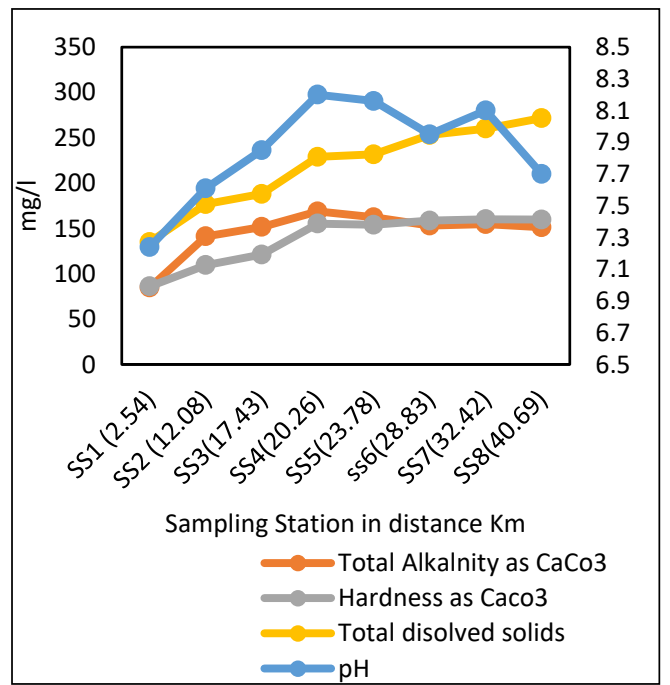

Fig. 4: Variation of $\mathrm{pH}$, TDS, $\mathrm{CaCO}_{3}$ and TA during pre-monsoon season.
Total dissolved solids: The level of pollution of any water sample is directly proportional to its dissolved solid content. The data computed for the Total Dissolved Solids (TDS) in the pre-monsoon and the post-monsoon seasons for station 1 were 134.96 and $120.3 \mathrm{mg} / \mathrm{L}$ respectively. However, from the stations 2 to 8 , the TDS values vary from 176.75 to 271 $\mathrm{mg} / \mathrm{L}$ and 133.54 to $234.6 \mathrm{mg} / \mathrm{L}$ during pre-monsoon and post-monsoon seasons, respectively (Figs. 4 \& 5).

The higher TDS values occurred during the pre-monsoon season. Throughout all the season, there was a sudden spike in the values observed from station 1-2. Beyond station 2, the TDS value to increase gradually from station 2 through to 8 . The increase in the TDS value from stations 2-8 is likely caused by the release of untreated domestic wastewater. Some researchers have observed that a high level of TDS is a pointer to industrial pollutions (Khare \& Unni 1986). However, the TDS values measured throughout all the seasons are within the acceptable threshold for drinking water, which is 500 mg/L (IS: 10500, 1992).

Dissolved oxygen: Previous research has established that a groundwater source must have a minimum of $2 \mathrm{mg} / \mathrm{L}$ of dissolved oxygen to be able to support higher life forms. For instance, the game fish requires at least $4 \mathrm{mg} / \mathrm{L}$ of DO to thrive, and some species may require even more. Besides its ability to support life, DO levels are also crucial in the aquatic environment because the end product of various chemical and biochemical reaction where oxygen is low give rise to unsightly colours and foul taste and odour in water.

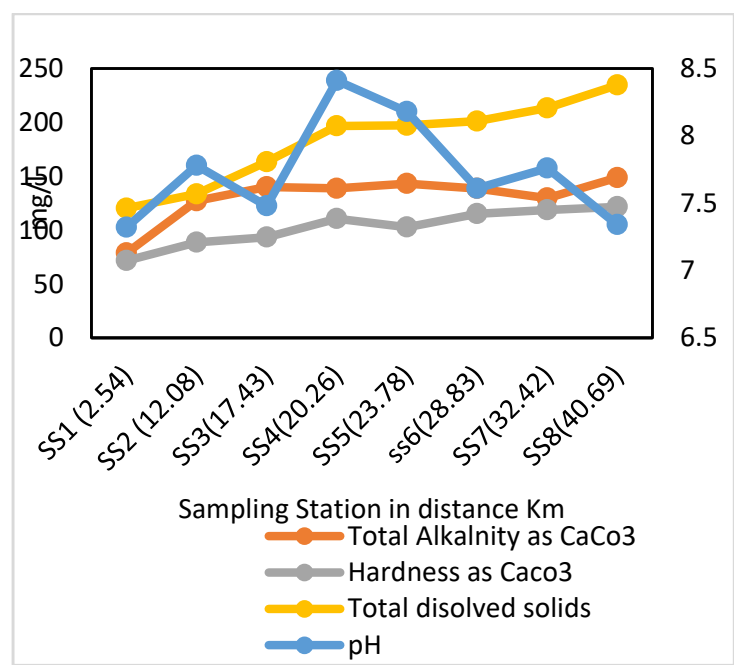

Fig. 5: Variation of $\mathrm{pH}$, TDS, $\mathrm{CaCO}_{3}$ and TA during post-monsoon season. 
The present study reveals that the average DO value during the pre-monsoon and post-monsoon seasons are 7.65 and $8.1 \mathrm{mg} / \mathrm{L}$, respectively. On the other hand, the DO values for station 4 is between 4.65 and $5.3 \mathrm{mg} / \mathrm{L}$, respectively. The values measured continued to recover till station 5 , then it increased from station 6 to 8 and attained up to 8.1 and 8.4 $\mathrm{mg} / \mathrm{L}$ during the pre-monsoon and post-monsoon seasons respectively (Figs. $6 \& 7$ ).

The differences in the DO values from station 2-6 can be largely attributed to oxidation of dissolved organic matter introduced into the water system through sewages from Rajanahalli to Nadiharahalli, and other villages located on the river banks. The improvement of DO after station 5 is due to atmospheric aeration as there is no further discharge of waste into the water system. As per $\mathrm{CPCB}$, the content of Dissolved Oxygen in the river system aligns with the

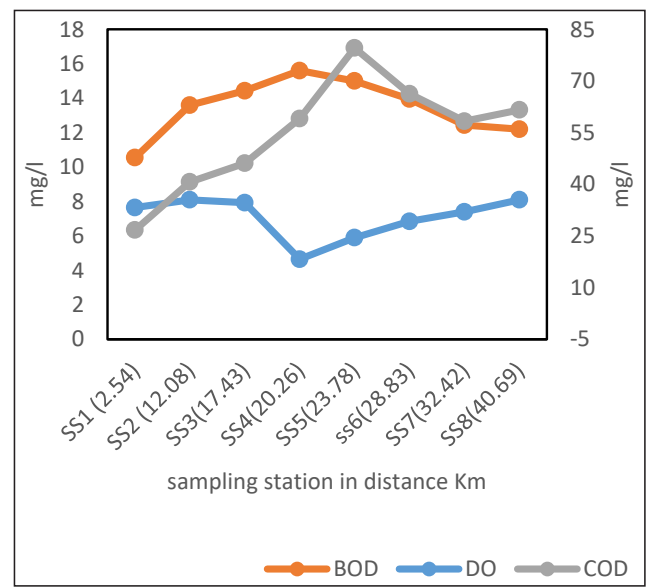

Fig. 6: Variation of BOD, DO and COD during pre-monsoon season.

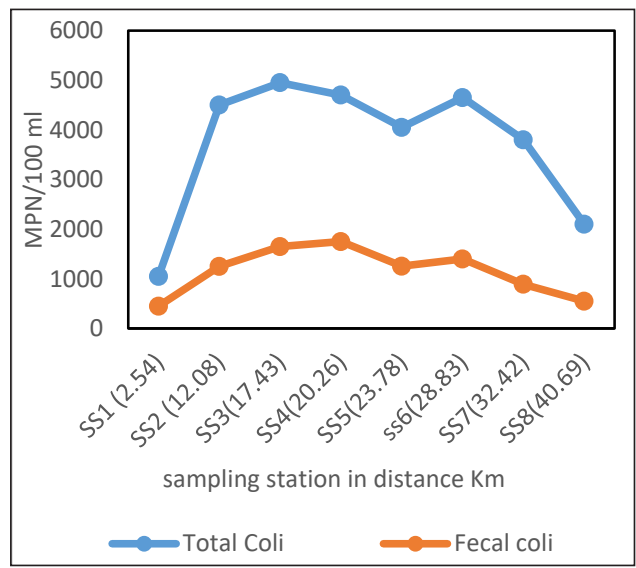

Fig. 8: Variation of Total Coli and Faecal Coli during pre-monsoon season. standards of Class "C" making it drinkable if subjected to conventional treatment and disinfection is done.

The higher atmospheric temperature and increase in the decomposition of organic matter by microbes could be responsible for the reduction of DO during the summer months. The research carried out on Ganga river water quality at Gazipur shows a similar conclusion (Shukla et al. 1992).

Total coliform: When a water body has been contaminated with faecal material, traces of faecal coliform bacteria will be observed in the water body. There is a high likelihood that such water is already contaminated with virulent pathogens such as bacteria and viruses that exist in faecal materials. The occurrence of faecal coliform in natural water can be as a result of contamination through the discharge of domestic sewage, or nonpoint sources of waste from human and animals. The present research shows that the total coliform count for station

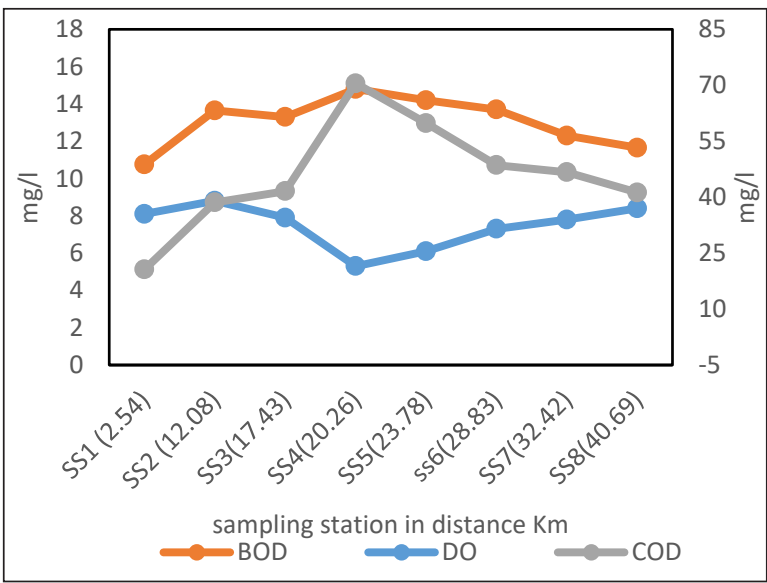

Fig. 7: Variation of BOD, DO and COD during post-monsoon season.

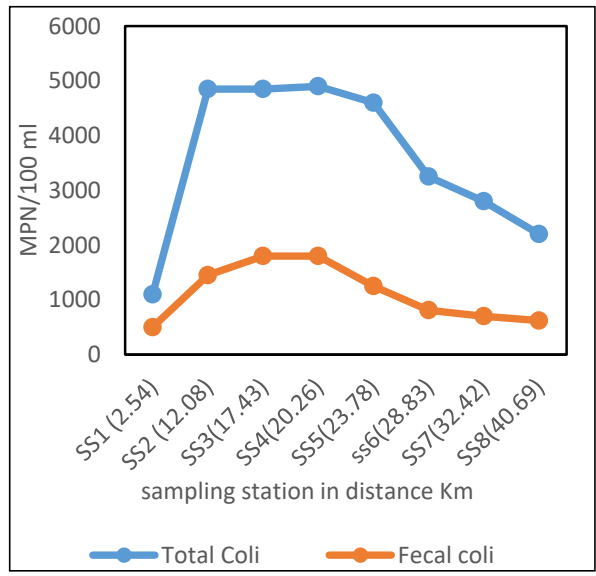

Fig. 9: Variation of Total Coli and Faecal Coli during post-monsoon season. 
1 was 1050 and $1100 \mathrm{MPN} / 100 \mathrm{~mL}$, for the pre-monsoon and post-monsoon seasons respectively (Figs. 8 \& 9). For the remaining sampling site (SS2-SS8), the value measured ranges from 550 to 4950 and 2200 to $4850 \mathrm{MPN} / 100 \mathrm{~mL}$ for the pre-monsoon and post-monsoon seasons, respectively. The analysis reveals that the values increased sharply, from station 1 to 2 . The same trend continues gradually from stations 3 to 8. Due to the by the discharge of domestic waste at locations upstream of the sampling stations.

\section{CONCLUSION}

The present study report on water quality assessment in term of physiochemical and biological parameters across $40.5 \mathrm{~km}$ stretch of river Harihara show a sharp increase in values in the readings obtained from upstream of Kumarapatanam to its downstream sampling site. The values observed from stations 3-5 increased gradually. However, all the values are within the acceptable threshold for drinking water (IS: 10500, 1992). The fact that the values measured are increasing while progressing downstream Kumarapatanam shows that there is an urgent need to keep pollution under check by relevant authorities. This intervention parameter within the acceptable limits as industrial activities and the population continues to rise. The BOD value measured at all the monitoring stations exceeds 3 $\mathrm{mg} / \mathrm{L}$, except at the upstream Mudenur Village. The highest value for BOD $(10.95 \mathrm{mg} / \mathrm{L})$ was obtained. The highest value for the BOD was measured during the pre-monsoon season at $19.9 \mathrm{~km}$ upstream of sampling station 1 . Taking inference from the various BOD measurements, the only part of the stretch that qualified as Class $C$ is up to $3 \mathrm{~km}$ stretch from the upstream boundary. The water obtained from this part of the river is good for drinking, after conventional treatment, and disinfection. However, the results show that the river water derived from 12.8-40.5 km stretch of the area is designated as Class D. As such, the water could be applied for irrigation, industrial cooling, fishery, and control wastewater disposal.

\section{REFERENCES}

APHA 1998. Standard Methods for the Examination of Water and Wastewater. American Public Health Association, 20th Ed., Washington DC.

Gleick, P.H. 1993. Water in Crisis: A Guide To The World's Fresh Water Resources. Oxford University Press, New York.

Haribhau, M. G. 2012. Trace metals contamination of surface water samples in and around Akot city in Maharashtra, India, Res. J. Recent Sci., 1(7): 5-9.

Khare, S.K. and Unni, K.S. 1986. Changes in physico-chemical factors and distribution of periphyton in Pollar river Proc. In: K. S. Unni (Ed.), All India Seminar on Water Quality Around Urban Ecosystems.

Kumar, 2012. Physico-chemical and microbiological analysis of underground water in and around Gwalior City, Madhya Pradesh, India, Res. J. Recent Sci., 1(6): 62-65.

Manimaran, D. 2012. Groundwater geochemistry study using GIS in and around Vallanadu Hills, Tamil Nadu, India. Res. J. Recent Sci., 1(7): $52-58$.

Patil, A. 2012. Impact of physico-chemical characteristics of Shivaji University lakes on phytoplankton communities, Kolhapur, India. Res. J. Recent Sci., 1(2): 56-60.

Pal, U.C., Bandopadhyay, G. and Santra, S.C. 1986. Importance of phytoplankton study in the assessment of water quality-A case study from Bhagirathi-Hoogly river basin. Proc. All India Seminar on Water Quality around Urban Ecosystem and their Management, pp. 27-29.

Raina, V., Shah, A.R. and Ahmed, S.R. 1984. Pollution studies on river Jhelum-1. An assessment of water quality, Indian J. Environ. Hlth., 26(3): 187-201.

Ranjan, R. 2012. Water quality monitoring of groundwater resources around sugar factory, near East-West Champaran Border, Bihar, India, Res. J. Recent Sci., 2(7): 79-81.

Ranjith, S., Shivapur, A.V., Kumar, P.S.K., Hiremath, C.G. and Dhungana, S. 2019. Water quality model for streams: a review. Journal of Environmental Protection, 10: 1612-1648.

Rao, S.N., Chaubey, R. and Srinivasan, K.V. 1990. Ganga waters quality in Bihar. Indian J. Environ. Hlth., 32: 393-484.

Shukla, 1992. Physico-chemical and Bacteriological properties of the water of river Ganga at Ghazipur, Comp. Physiol. Ecol., 17: 92-96.

Singh, D.K. and Singh, C.P. 1990. Pollution studies on river Subernarekha around industrial belt of Ranchi (Bihar). Ind. J. Environmental Health, 32: $26-83$.

Unni, 1992. Preliminary hydro biological studies on river Narmada from Amarkantak to Jabalpur. In : S. R. Mishra and D. N. Saksena (Ed.) Aquatic Ecology.

Unni, K.S. 1985. Comparative limnology of several reservoirs in Central India. Int. Rev. Gesanten. Hydrobiol., 70: 845-856. 